\title{
우리나라 무상원조사업의 중장기 정책 및 전략 要約
}

전 승 훈 외 4 명 / (사) 한국개발전략연구소

1. 개발원조는 국제사회의 구성원의 일원으로서 국제사회가 기대하는 책무를 다함과 동시에, 이 를 통하여 자국의 이익도 도모하고자 하는 것이 다. 따라서 우리나라의 개발협력 방안을 검토함 에 있어서는 우선 개발원조의 관점에서 국제사 회의 과제와 동향을 파악하는 것이 첫 번째의 과제이다.

2. 개발원조는 1960 년대 이래 OECD/DAC의 설 립을 계기로 국제사회의 기본적인 과제로서 본 격적으로 추진되어 왔다. $\mathrm{OECD/DAC는} \mathrm{개발}$ 원조의 국제적 기준을 제시하고 국제사회의 빈 곤완화와 경제적 발전을 지원토록 협의해 나가 고 있다.

- $\mathrm{OECD} / \mathrm{DAC}$ 가 수립한 $\mathrm{ODA}$ 의 국제적 기준 중 양적목표는 (i) 원조공여국GNI $1 \%$ 의 순자금 공 여, (ii) 공여국 GNI $0.7 \%$ 의 ODA 공여, (iii) 저 개발국에 대한 GNI 대비 $0.15 \%$ 의 ODA 배정
등이다. 이중 GNI 대비 ODA 비율은 원조수준 을 결정하는 중요한 지표이다.

- 아울러 $\mathrm{ODA}$ 의 질적 수준을 제고하기 위한 질 적 목표는 (i) $\mathrm{ODA}$ 중 증여가 차지하는 비율(증 여비율)의 제고 (ii) 양허조건을 나타내는 증여 율의 $86 \%$ 수준유지 (iii) 비조건부 원조비율의 제고 등이다.

- 최근 ODA 추이를 보면, 1990년 530억 달러에서 1997년에는 483억 달러로 감소하였다가 최근 천년개발목표(MDGs)선언 이후 2003년 690억 달러, 2004년은 786억 달러로 상당한 증가 추세 에 있다. 2004 년 현재 최대의 원조액을 제공하는 국가는 미국, 일본, 프랑스, 영국, 독일 등의 순이 다. GNI 대비 ODA의 비율을 보면 2004년 현재 국제적 권고사항인 $0.7 \%$ 를 초과한 국가는 덴마 크, 노르웨이, 네델란드, 스웨덴, 룩셈부르크 등 이며 그 이외 국가들은 $0.7 \%$ 에 미달하고 있으며, $\mathrm{OECD} / \mathrm{DAC}$ 회원국의 평균은 $0.26 \%$ 이다. 
3. 2000 년대에 들면서 빈곤완화가 국제사회의 새 로운 화두로 등장하고 있으며, 그 배경에는 다 음과 같은 세 가지의 인식이 있다.

- 인류사회의 항구적 목표, 즉 결핍으로부터의 자유, 공포로부터 자유, 인간으로서의 존엄성 을 지니고 살아갈 자유(UN, 〈보다 확대된 자 유: 모두를 위한 개발과 안보 및 인권>, 2005) 에 대한 인식을 새롭게 하게 되었다.

a 그런데 지난 25 년 동안 많은 국가들의 빈곤이 개선되지 못하고 있어서 이러한 인류사회의 목 표가 위협받고 있다.

- 아울러, 최근 국제사회의 안전이 주요 이슈로 제기되고 있으며, 빈곤이 이러한 안전을 위협 하는 갈등의 씨앗이라는 인식이다. 따라서 빈 곤국가의 빈곤완화와 경제개발을 지원하는 것 은 안보적 예방수단이자, 국제 안보체제의 기 반으로 간주되고 있다.

4. 이에 따라, 국제사회는, 2000 년 $\mathrm{UN}$ 주도로 천년개발목표(Millennium Development Goals, MDGs)를 선언하고, 빈곤에 대한 범지 구적 목표를 정하고 이를 달성하기 위한 공적 개발원조의 확대와 그 효과성 제고를 위한 노 력을 강화하고 있다.

a 천년개발목표(MDGs)는 8개 목표(Goals)와 18 개 세부목표(Targets)로 구성되어 있는데, 그 핵심은 국제사회의 빈곤완화와 이를 위한 범지 구적 파트너십에 있다.

- 동 목표는 2015 년까지 하루 소득 1달러 미만의
인구비율 그리고 기아인구를 절반으로 감축하 는 것을 목표의 골자로 설정하고 있다.

5. 동 목표를 달성하기 위하여 구체적인 정책방안 도 함께 강구되고 있다. 이는 (1) 개발원조규모 의 증대, (2) 전 지구적 파트너십의 강화, (3) 원조의 효과성 제고, 그리고 (4) 거버넌스의 중 시의 네 가지로 볼 수 있다.

6. (1) 원조규모의 증대와 관련하여, 2005년 제59 차 UN총회에서 선진국들은 2015년까지 MDGs 달성에 필요한 GNP 대비 $0.7 \%$ 의 원조재원을 동원하는 계획을 재차 확인하였다. 이를 위하여 2009년까지 ODA의 GNP 대비 최소한 $0.5 \%$ 를 달성하고, 동시에 최빈국에 대하여는 GNP대비 $0.15 \%$ 내지 $0.2 \%$ 를 지원하도록 권고하고 있다.

7. (2) 범 지구적 파트너십의 강화는 2002년 〈몬 테레이 개발재원 회의〉와 〈요하네스버그 지속 가능한 발전에 관한 세계 정상회의>를 통하여 계속 강조되고 있다. 이의 구체적 실천방안으 로 개발도상국과 선진국의 상호책임에 기초하 여 모든 개도국은 MDGs 달성을 위한 국가발 전전략을 2006년까지 수립하도록 하는 것을 포함하여 개발재원, 무역 및 채무구제에 관한 행동계획을 제시하고 있다.

8. (3) 원조의 효과성 제고와 관련하여, $U N$ 은 $\mathrm{MDGs}$ 목표달성을 위하여 선진국들의 원조 시 
스템을 전면적으로 조정하여야 한다고 주장하 고 있으며(UN, 〈개발에의 투자: 천년개발목표 달성을 위한 실천계획>, 2005년), 2005년 2월 〈원조효과에 관한 파리선언〉은 〈몬테레이 컨센 서스(2002)〉와 〈원조조화에 관한 로마선언 (2003)〉 및 〈마라케시 메모랜덤(2004)〉의 공약 이행 상항을 점검하고 개발원조 방식에 있어 대폭적인 개혁조치를 요구하고 있다. 동 선언 은 다음과 같은 원조의 5 대 원칙을 준수하도록 권고하고 있으며, 이들에 대한 성과지표를 개 발하고 이의 구체적인 이행 기한을 제시하고 있다 (파리선언3부).

- 수원국의 주인의식(Ownership)

- 수원국 개발의제에 맞는 원조일치 (Alignment)

- 공여국가 간 원조 조화(Harmonization)

- 원조성과의 관리(Managing for results)

- 호혜적 책무(Mutual accountability)

9. 원조 효과성의 제고를 위한 계속적인 과제의 하나가 원조의 비구속성(untying) 이다.

- 1970년대 이래 양자간 원조의 언타이드화가 계 속되고 있다. 1980년대 초에는 DAC회원국의 양자간 원조의 $60 \%$ 가 비구속성 원조였는데, 1990년대에는 이것이 $80 \%$ 로 증가하였고, 2003년에는 92\%(기술협력을 제외한)에 달하고 있다. 비구속성 원조는 2002년부터 DAC회원국 이 최빈국에 대한 자금원조는 언타이드화에 합 의하였기 때문에 앞으로 계속 확대될 것이다.
10. (4) 관리능력(Governance)을 중시하는 입장 과 관련하여, 세계은행은 지난 50 년간 원조성 과에 대한 평가에서 원조와 경제성장 간에는 뚜렷한 상관관계가 없다는 것을 연구결과를 통하여 밝히고 있으며, UN을 위시한 국제기 구는 수원국의 관리능력(Governance) 제고 를 위한 논의를 활발하게 진행하고 있다.

- 세계은행은 수원국의 관리능력(Governance) 에 따라 원조의 성과가 결정된다는 것을 아프 리카 7개국에 대한 비교연구 및 Lopez의 중 남미 3국에 관한 연구를 바탕으로 밝히고 있 다. 동 연구는 "아프리카의 거의 모든 나라에 서 지난 삼십 년 동안 행정 역량의 체계적인 퇴보 현상이 발생했으며, 다양한 형태의 외부 원조가 아프리카 전 지역 $\mathrm{GDP}$ 의 $10 \%$ 를 넘어 설 정도로 가속화되던 시기에 이러한 퇴보 현 상이 발생했다는 점에 주목하여야 한다” 고 논 하고 있다.

- UN, 세계은행, $\mathrm{OECD}$ 등 국제기구에서 수원 국의 능력개발(Capacity building) 향상을 위 한 논의가 활발하게 진행되고 있으며, 공여국 의 원조에 있어서 수원국 정부의 행정역량 (Governance) 발전을 중시하는 경향이다.

- 이와 관련하여 $\mathrm{ODA}$ 의 개념에 안보지원 활동 을 포함시키자는 논의도 제기되고 있다.

11. 이러한 국제적 동향에 부응하여 선진국 원조 국가들도 MDGs 실현에 적극 동참하고 있다.

- 많은 $\mathrm{DAC}$ 회원국들이 MDGs 달성을 위한 
$\mathrm{ODA}$ 노력과 의지를 국제사회에 천명하고 구 체적인 MDGs 실천방안을 제시하고 있다.

- 그 일환으로 원조규모를 증대시키고 있는 바, 2004년 DAC 회원국의 ODA 규모는 786억 달러로서 사상 최고를 기록하였고, $\mathrm{EU}$ 는 2006년까지 ODA/GNI 비율을 0.39\%까지 확 대할 것을 결의한 바 있으며, 미국은 새천년 개발계정 $(\mathrm{MCA})$ 로 3 년간 매년 50 억 달러씩 추가 공여키로 하였다.

- 원조의 효과성을 제고하기 위하여 지난 10 여 년 동안 $\mathrm{DAC}$ 회원국 중 최소 9 개국 이상이 $\mathrm{ODA}$ 조직 개편을 포함한 관리체계의 개혁을 추진하였다.

12. 이상과 같이 개발원조의 국제적 환경은 역사 적으로 과거 어느 시기보다도 국제사회의 빈 곤완화와 이를 위한 개발원조의 확대 및 국제 사회의 파트너십의 강화를 요구하고 있는 바, 한국도 이러한 국제적 노력에 적극 동참할 것 이 요구된다.

13. 한국의 중장기 무상원조사업의 정책을 연구 하는 두 번째의 과제는 한국의 개발원조를 무 상원조사업 중심으로 분석 평가하는 것이다.

14. 첫째, 한국의 개발원조를 평가해 보면, 국제적 기준에 비추어 상당히 뒤떨어져 있음을 알 수 있다.
15. (1) 원조의 규모에 있어서 한국의 공적개발원 조의 국민소득 비중이 선진국과 비교할 수 없 을 만큼 최하위 수준에 머물러 있다.

- 2004년 ODA총액은 4.2억 달러로서 이의 $\mathrm{GNI}$ 비중은 $0.06 \%$ 이다. 후자의 경우, $\mathrm{DAC}$ 회원국 평균의 $1 / 4$ 수준이고, 우리와 경제규모 가 비슷한 네덜란드 $(0.74 \%)$, 스페인(0.26\%) 의 $1 / 4-1 / 12$ 에 불과하며, 1 인당 소득수준을 유사한 포르투갈(0.63\%), 뉴질랜드(0.23\%)와 도 $1 / 4-1 / 10$ 수준이다. 1 인당 $\mathrm{ODA}$ 분담액은 8달러로서 노르웨이(281 달러)와 DAC평균 (69 달러) 과는 비교가 되지 않는다.

16. (2) 원조의 질에 있어서도 증여율(grant element), 증여 비율(grant share), 원조의 구속성 등의 기준에서 볼 때 마찬가지로 뒤떨 어져 있다.

- 증여율을 보면, 2004년 기준 $86.7 \%$ 로서 $\mathrm{DAC}$ 회원국 중 최하위 수준이다.

믕여 비율도 $39.83 \%$ 로서 $\mathrm{DAC}$ 평균(89.7\%)과 도 상당한 차이가 있다.

- 원조의 언타이드율은 $19.4 \%$ 로서 $\mathrm{ODA}$ 전액 을 언타이드로 제공하고 있는 영국과 아일랜 드등은 물론이고, DAC 평균(92\%)에도 크게 뒤져 있다.

17. (3) 국제적 조화와 일치의 측면에서 한국은 상 당히 미흡하다. 한국은 $\mathrm{OECD/DAC}$ 회원국으 로 가입하지 않고 있다. 그에 따라 한국의 개 
발원조를 보면 여러 가지 조건에서 국제적 기 준과는 조화와 일치를 기하고 있지 못하다.

- 원조사업의 효과성에 관한 파리선언의 5 대 원 칙, 즉 (1) 수원국의 주체성(Ownership), (2) 원조의 일치(Alignment), (3) 원조 조화 (Harmonization), (4) 결과를 위한 관리 (Managing for development results), 그리 고 (5) 호혜적 책무(Mutual accountability)의 기준에서 볼 때에도 국별 원조계획이 미흡한 체 영세한 규모로 많은 국가를 대상으로 사업 을 하고 있기 때문에 상당히 미흡한 것으로 평 가된다.

18. 둘째, 한국의 무상원조사업을(1) 지원규모와 대상, (2) 사업의 컨텐츠, (3) 사업관리 시스템 의 세 가지 측면에서 분석한다.

19. (1) 지원 대상에 있어서 다수 국가를 대상으로 백화점식 영세한 사업수행하고 있어서 그 효 과성이 낮을 수밖에 없다.

- 2004년도 $\mathrm{KOICA}$ 의 협력대상국은 약 138 개 국이며 이라크, 아프간을 제외한 협력사업비 는 약 1 억 달러 수준이다. 1 개국당 평균지원액 은 74 만 달러이지만 실질적으로 주요지원 대 상지역인 아시아 국가를 제외한 73 개국에 대 하여는 연간 10 만 달러 미만인 셈이다.

- 원조 선진국의 경우 이와는 판이하게 달라서, 영국은 우리의 20 배의 원조규모에 대상 국가 는 43 개국, 네덜란드는 11 배 원조규모에 36 개
국가를 대상으로 하고 있으며, 덴마크의 경우 원조대상 국가를 1998 년 100 개 국가에서 2004년에는 36 개 국가를 대상으로 계속 줄이 고 있다.

20. (2) 무상원조사업의 내용 면에서 볼 때, 원조 사업의 기본 목표인 빈곤완화에 대한 나름대 로의 처방을 제공하고 있지 못하다.

a 국별 원조계획(Country Programming)이 없 는 여건에서 빈곤극복을 위한 체계적인 컨텐 츠가 개발되지 않고 있는 실정이다.

- 국별 원조계획(Program)이 미흡한 채, 일반 적인 사업(Project)을 아주 다양한 형태로 공 여하고 있으며, 그 내용도 한국제도의 해설 또는 물자제공 수준을 크게 벗어나지 못하고 있는 실정이다.

a 국제적으로 독특한 한국의 빈곤극복 및 경제 발전의 노하우가 제대로 활용되지 못하고 사 장되고 있는 것이다. 그 일례로 빈곤국가에서 목말라하는 한국 새마을 운동에 대한 충실한 교본도 없는 실정이다.

21. (3) 사업이 제대로 관리될 수 있기 위하여서는 일련의 사업관리 체계가 지켜져야 하는데, 실 제의 원조사업 관리에 있어서 사업의 기획, 실 시, 감독, 평가 등의 일련의 사업관리 체계가 제대로 살아있지 못하다.

- 기획은 사업전체의 목표, 수단, 가용재원, 책 임소재, 사업지속가능성 및 단계별 평가기준 
을 설정하는 작업이다. 사업기획은 사업전체 에 영향을 미치고 성과와 직결되기 때문에 사 업관리자의 기획력은 사업관리의 핵심이다. 현재 우리는 기획력도 부족하고 체계도 갖추 고 있지 못하다.

- 사업의 시행에 있어서는 시행 주체의 적정성 과 시행관리의 융통성이 우리에게 부족하다. 개발협력 사업의 기획은 원조기관의 몫이고, 시행은 시장에서 조달하는 것이 원칙이다.

- 우리는 평가 및 환류 과정이 특히 소홀히 여겨 지고 있다. 우리나라는 객관적이고 독자적인 평가체계를 구축하지 못하고 있다. 평가를 통 해 생성된 주요한 정보나 결과를 효과적으로 활용하지 못하고 있다. 평가 결과를 다음 사 업의 기획 자료로 활용할 수 있는 환류장치 및 결과를 공개적으로 공유하는 시스템도 불충 분하다.

22. 셋째, 우리나라 무상원조사업을 각론으로 다 음의 네 가지 사업형태별로 분석한다.

(1) 인력협력사업

(2) 개발협력사업

(3) 민간 국제협력사업

(4) 개발협력사업 인프라

23. (1) 인력협력 사업으로서 연수생 초청 사업은 한국 개발협력 사업 중에서 개발도상국가들로 부터 상당히 인기가 있는 사업이지만, 개발도상 국가의 수요를 제대로 충족하기에는 미흡하다.
- 연수 프로그램이 국가별 원조계획과 제대로 연계되어 있지 못하다.

a 연수 내용이 단순히 한국의 경험을 소개하는 수준에 그칠 것이 아니라, 그들이 당면하고 있는 과제에 대하여 한국의 경험을 살려서 그 들에게 필요한 지식과 노하우를 공급할 수 있 는 연수의 맞춤 서비스가 되어야 한다.

- 이를 위해서는 연수를 본업으로 하지 않는 출 연기관 위주의 연수로는 그러한 서비스를 하 기 어렵다. 한국의 개발경험을 상품화하고 이 를 전달하는 것을 본업으로 하는 전문적인 컨 설팅 기업 또는 기관에 의하여 수행될 수 있도 록 하여야 한다.

a 전문가를 파견하는 경우에도, 우선 전문가 수 요를 결정함에 있어서 국가별 원조계획과 연 결되어 있지 못하고 있고 개별 인사의 단기 파 견에 치중되어 있어서, 그 효과성이 낮다.

a 봉사단파견사업에 대해서는 파견인력의 증대 에 대응하여 개발협력의 취지를 충분히 살릴 수 있도록 봉사의 질적 수준을 유지하고 관리 방식을 개선하는 것이 과제가 되고 있다.

24. (2) 개발협력 사업에 있어서는 개발협력 사업 의 범주에 속하는 것으로 개발조사사업과 프 로젝트가 있다.

- 우선 개발협력 사업이 앞의 인력협력 사업과 마찬가지로 국별 원조계획과 연계가 미흡하 여 그 성과도 그만큼 낮을 수밖에 없다. 모든 개발원조사업은 기본적으로 해당 수원국의 
발전을 위한 정책 프로그램의 일환으로 설계 되고 추진되어야 한다.

- 개발조사사업은 국별 원조계획 하에서 정책 프로그램을 실현하기에 적합한 사업형태이 다. 이를 더욱 확대 발전시켜나가야 한다.

- 프로젝트형 사업의 경우 아직 한국적 발전경 험의 노하우를 활용하는 컨텐츠가 제대로 개 발 되어 있지 못하여 주로 하드웨어를 건설하 는 것에 치중되어 있다.

25. (3) 개발원조에 있어서 시민사회, $\mathrm{NGO}$ 등과 관련하여 새로운 시각에서 접근하여야 한다.

- 개발원조기관은 이들 민간 기구를 개발원조 의 동반자로서 모든 사업과정에서 긴밀하게 협력하도록 하여야 한다.

- 이를 위해서는 사업수행 방식에 있어서 과감하 게 시장에 의존하도록 하는 것이 필요하다.

26. (4) 개발원조가 효과적으로 수행될 수 있기 위하여서는 개발원조의 산업인프라가 충분히 갖추어져 있어야 하며, 그 중에서 가장 중요 한 것이 개발협력 컨설팅 산업이다.

- 우리나라는 국제적 수요가 높은 정책경험과 같은 메뉴와 실무경험을 가진 전문가가 있지 만, 개발컨설팅산업이 형성되지 못하고 있다.

- 이는 우리의 개발원조 자체의 역사가 일천한 점과 아울러 우리의 개발원조 사업수행 방식 이 아직 시장을 제대로 활용하지 못하고 있기 때문이다.
- 2003년 아시아개발은행(ADB)의 컨설팅 프로 젝트 수주실적을 보면, 선진국은 물론이고, 중국, 인도네시아, 파키스탄, 필리핀과 같은 아시아지역의 개도국들도 상당한 수주실적을 보이고 있으나, 한국은 전무한 것으로 나타나 있다.

27. 이상과 같이 한국의 개발원조에 대한 평가로 부터 몇 가지 특이점을 도출할 수 있다.

- 한국은 개발원조의 부담 수준과 원조의 질적 지표에 있어서 국제사회의 기준에 크게 미흡 한 실정이다.

- 한국의 무상원조 수행방식도 역사가 일천하 여 선진국의 기준에서 볼 때 상당히 비효율적 이다.

- 앞으로 개발원조에 있어서 국제적 조화와 일 치가 강조되는 관점에서 볼 때, 한국의 개발 원조는 양적이나 질적 측면에서 상당한 변화 가 요구되고 있다.

- 한국이 생존기반을 해외에 두고 있으며, 해외 와의 협력관계가 한국인의 생존과 발전에 절 대적인 영향을 주는 요소임을 고려할 때, 현 재와 같은 개발원조의 지속은 국익의 차원에 서 슬기롭지 못한 것이다.

28. 따라서 본 연구의 주 과제는 이상과 같이 개 발원조의 국제적 환경과 한국의 무상원조사 업을 위주로 한 개발원조에 대한 분석을 토대 로 바람직한 무상원조사업 중장기 정책방향 
을 제시하는 것이다.

29. 이와 같은 연구의 목적은 구체적으로 두 가지 의 연구를 통하여 완성될 수 있을 것이다.

- 하나는 한국적 여건에서 개발원조를 어떻게 추진하는 것이 바람직한 가를 검토함으로써, 그러한 정책을 실현할 수 있는 중장기 정책의 틀(Framework)을 제시하는 것이고, 다른 하 나는 그러한 정책의 틀에서 담을 구체적인 내 용(Contents)일 것이다.

- 전자는 제도, 하드웨어라고 볼 수 있고, 후자는 컨텐츠, 소프트웨어라고 볼 수 있을 것이다.

30. 전자에 대한 연구를 위하여 우선 한국의 개 발원조의 여건 하에서 개발원조를 어떻게 추 진하는 것이 국가적으로 바람직한가를 검토 한다.

31. 한국의 개발원조는 두 가지의 환경적 조건 하 에서 수행되는 것으로 볼 수 있다.

- 개발원조는 국제사회에서 구성원으로서의 책 무를 다하는 것이므로 개발원조에 대한 국제 적 동향이 하나의 환경이 된다.

a 다른 하나는 재정적 제약성이다. 개발원조는 주로 재정에서 충당하는 것이므로 재원은 전 적으로 재정상 제약을 받게 된다.

32. 먼저 국제적 원조환경에 있어서는, 지금 지구 촌에서는 빈곤 완화가 최대의 국제적 과제가
되고 있으며, 이를 국제적으로 원조 규모를 크게 늘리는 동시에 원조의 효과성을 높이도 록 원조 방식을 개편하면서 국제적 조화와 일 치를 강화하는 방향으로 나아가고 있다. 한국 의 개발원조도 이러한 환경 하에서 국제사회 의 구성원으로서 이에 적극 부응하여야 하는 과제를 안고 있다.

33. 다음으로 한국의 재정 여건을 보면, 개발원조 예산을 크게 늘려나가기가 점점 어렵게 되고 있다.

- 우선 경제가 고도성장의 단계를 벗어나 성장 세가 크게 둔화하고 있다.

- 인구의 노령화가 급속하게 진행되어 그 만큼 경제의 활력은 둔화되는 대신에 복지지출에 대한 부담을 크게 늘 수밖에 없다.

a 특히 남북관계에 있어서 엄청난 재정부담을 감당하지 않을 수 없는 입장이다.

- 이러한 재정상의 제약성에 더욱 어려움을 주 는 것은 원조에 대한 국민적 지지기반이 아직 취약하다는 것이다.

34. 한국은 이렇게 국제사회에서의 높은 책무와 재정적 제약성의 괴리 하에서 개발 원조를 수 행하여야 하는 어려움이 있다. 전자를 따르자 면 개발원조 규모를 크게 늘려야 하나 후자의 제약으로 그럴 형편이 못되고 그러다가는 국 제적 책무를 소홀이 하는 것이 되고 만다. 
35. 이러한 상황에서 취할 대안으로서는 (1) 재정 적 제약성 아래에서 현재의 개발원조의 규모 와 방식을 그대로 유지하는 것, (2) 재정상 제 약성을 효과적으로 극복하면서 국제적인 책무 를 다하는 것의 두 가지를 생각해 볼 수 있다.

36. (1)안은 한국의 여건에서 국가이익에 부합하 는 것이 못된다.

a 먼저 한국인의 삶의 기반인 땅은 무엇보다 부 존자원이 빈약하고, 석유를 전적으로 수입하 여야 하며, 거기다가 식량인 곡물도 $70 \%$ 정도 를 수입에 의존하여야 하는 실정이다.

- 이러한 좁은 땅에 가진 자원이 없이 많은 인구 가 살아야 하는 한국으로서 그 생존 기반은 바 깥에서 찾을 수밖에 없다. 즉, 무역이 한국인 의 생명선(Life-line)이다.

- 이러한 삶의 조건에서 한국인이 지속적으로 생존을 확보하고 삶의 수준을 향상시켜 나갈 수 있는 길은 두 가지로 볼 수 있다.

- 하나는 물론 글로벌 시장에서 지속적으로 수 출을 해나가면서 에너지 및 원자재를 안정적 으로 확보하는 것이다.

- 다른 하나는 생존기반이 되는 국제사회에서 신뢰받는 동반자로서 인정받을 수 있어야 할 것이다. 국제사회에서 한국이라는 브랜드의 가치가 인정받을 수 있어야 하는 것이다.

37. 그런데 이 양대 축의 달성은 개발원조와 밀접 한 관계를 가진다.
- 전자의 글로벌 시장에서의 안정적 수출을 유 지할 수 있기 위한 기초적 조건은 (1) 끊임없 는 생산성 향상과 기술 혁신으로 그 시장에서 경쟁력을 확보할 수 있어야 할 것, (2) 우리가 즐길 수 있는 새로운 시장을 개척할 수 있어야 할 것이다.

- 후자의 국제사회에서 신뢰받는 한국의 브랜 드는 어떻게 창조할 수 있기 위해서는 무엇보 다 국제사회에서의 그 책무를 다하고 국제사 회의 발전에 기여할 수 있어야 할 것이다. 그 런데 개발원조는 후자의 국제사회에서의 책 무를 다하고 그 발전에 기여하는 일의 핵심적 수단이다.

- 개발원조는 전자의 국제시장에서 지속적으로 수출 경쟁력을 가질 수 있도록 하는데 있어서 도 서로간의 원만한 국제적 관계로 한국이 에 너지 및 원자재의 원활한 확보와 수출시장의 안정에 기여할 수 있도록 함과 아울러, 국제 관계에서 좋은 인적 및 지적 네트워크를 제공 하는 것이다. 특히 한국으로서는 총 249 억 달 러 무역흑자 중 개발도상국가로부터 무역흑 자 334억 달러(2004)를 달성하고 있는 입장 에서 더욱 그러하다.

- 뿐만 아니라, 개발원조 자체가 새로운 수출산 업으로서의 구실을 할 수 있다는 점이다. 오 늘날 국제적 원조가 엄청난 규모의 시장이 되 고 있으며, 한국은 이 시장에서 후술하는 이 유로 다른 어느 국가보다 경쟁력을 가지고 있 기 때문이다. 
38. 결론적으로, 위의 (1)안이 아니라 (2)안으로 한국은 개발원조를 통하여 국제사회에서 적 극적으로 기여하는 것이 자신의 이익과 생존 에 긴요하다. 재정적 제약성에도 불구하고, 자신의 개발원조를 통하여 국제사회에의 기 여도를 높이고 아울러 이를 통하여 개발원조 의 가치를 국민들이 제대로 인식할 수 있도록 함으로써 개발원조를 적극적으로 한국의 국 가전략으로 활용하는 것이다.

39. 그 방법은 제한된 재원으로 원조의 효과성을 최대로 살려서 국제사회의 핵심과제요 개발원 조의 목표인 국제사회의 빈곤 극복에의 기여 도를 획기적으로 높일 수 있도록 하는 것이다.

- 그렇게 될 경우 개발원조와 경제발전의 선순 환이 이루어지고 원조에 대한 국민적 기반도 강화되면서 개발원조의 재정상 제약도 극복 되어 더욱 적극적으로 국제사회에 기여하고 그에 따라 한국의 위상과 한국 경제발전에의 기여도 그만큼 가능하게 될 것이다.

40. 한국이 개발원조에 있어서 그 효과성과 국제 사회에서의 기여도를 높이는 길은 원조사업 에 있어서 한국이 가진 비교우위를 잘 살려서 원조의 목적인 국제사회의 빈곤 완화에 효과 적으로 기여할 수 있도록 하는 것일 것이다.

41. 한국은 이러한 개발도상국의 빈곤을 돕는 일 에 있어서, 선진국의 입장과는 달리, 아주 적
절한 입장에 있다.

- 선진국은 산업혁명 이래 지속적인 경제 사회 적 발전을 이루어 옴으로써, 현재의 개발도상 국가와 같은 상황을 일찍이 경험한 바가 없 다. 그들은 전혀 다른 시장 여건에서 발전하 여왔다. 그래서 그들은 개발도상국가들의 빈 곤 문제를 제대로 이해하지 못하고, 빈곤의 원인을 효과적으로 극복하는 방법에 대해 제 대로 알 수 없는 입장이다.

- 또한 개발도상국가로서는 그들에게 지배와 착취를 당한 경험을 가지고 있기 때문에 그들 의 도움의 순수성을 의심하고 그들의 뜻을 제 대로 받아드리기 어려운 입장에 있기도 하다.

- 그런데 한국은 세계 제 2 차대전 이후 독립한 140 여개 후진국 중에서 유일하게 선진화에 성공한 공화국으로서, 개발도상국가와 같은 환경에서 식민지 지배, 전쟁, 극단적 빈곤 등 개발도상국가의 보편적 고통유형 모두 경험 한 바이다. 여기에 같은 식민지 지배국가로서 선진국처럼 개발도상국가에 대한 역사적 부 채가 없는 입장에서 순수한 인도적 지원을 실 천할 수 있는 입장이기도 하다.

42. 한국은 이와 같은 입장에서 개발도상국의 빈 곤을 도울 수 있는 아주 독특한 경험과 노하 우를 보유하고 있다.

- 한국은 1960년대 초까지만 하더라도 전형적 인 저개발국가의 특성을 고스란히 지니고 있 는 국가였다. 
a 그러나 한국은 지난 반세기의 과정에서 빈곤 을 퇴치하고 근대적 산업국가로 변모하였다. 자동차, 반도체, 조선 등에서 세계적인 제조 기지가 되었으며, 1995년 국민소득 1만 달러 를 달성하고 $\mathrm{OECD}$ 회원국이 되었다.

- 세계 제 2 차대전 이후 많은 신생 독립국가들이 탄생하였지만, 한국처럼 국민소득으로 중진 국 이상으로 도약하면서 정치적으로 민주국 가로서 성공한 것은 역사상 그 유례가 드문 것 이다.

- 한국의 이러한 발전의 과정 자체가 빈곤 극복 을 지향하는 개발도상국가들로서는 아주 소 중한 교훈이 아닐 수 없다.

43. 이러한 입장의 한국으로서 개발협력의 전략 적 목표는 두 가지로 볼 수 있다.

a 하나는 한국이 스스로 보유하고 있는 빈곤극 복의 경험과 노하우를 살려서 빈곤 퇴치국 (Poverty eliminator)으로서의 국제적 명성을 획득하는 것이고, 다른 하나는 한국에 대한 브랜드 이미지를 제고하고 개발원조 산업을 발전시키는 것이다.

44. 이상과 같은 두 가지 전략적 목표를 실천하는 개발원조 사업 운용은 역시 두 가지로 특징화 될 수 있을 것이다.

ם 하나는 개발원조 사업 시스템을 혁신하고 개 발협력 사업을 글로벌 파트너십으로 추진하 는 것,
- 다른 하나는 국제사회의 빈곤 완화에 개발원 조의 초점을 맞추되, 한국적 비교우위를 최대 한 살린 한국적 개발협력 모델을 정립하는 것 이다.

- 그럴 경우 한국 브랜드의 가치가 크게 제고될 것이며, 그에 따라 경제발전의 기회가 지속적 으로 창출될 수 있을 것이다.

45. 이렇게 개발원조가 단순히 인도적 차원에서 국제사회의 책무를 이행하는 것에 그치지 않 고 한국인의 생존과 국가적 발전의 핵심적인 전략이라고 한다면, 우리의 무상원조 사업도 수동적으로 따라갈 것이 아니라 국가 전략적 차원에서 능동적으로 국제적 기준에 적합하 게 추진되어야 할 것이다.

46. 세 번째 연구과제의 주된 요소인 무상원조사 업의 중장기 정책의 틀(Framework)은 다음 의 네 가지 측면에서 제도적 기반이 갖추어져 야 할 것이다.

a 개발원조의 법적 장치.

- 개발원조 재원의 동원과 배분

- 사업관리 시스템

- 현행의 무상원조 사업별 개선과제

47. 첫째, 개발원조가 국가전략의 핵심적 요소라 고 한다면, ODA가 국가 전략적 차원에서 효 과적으로 수행될 수 있는 다음과 같은 제도적 장치에 의해서 추진되어야 한다. 
- $\mathrm{ODA}$ 의 이념 및 정책방향 및 추진 절차 등 을 포괄하는 기본법의 제정

- $\mathrm{ODA}$ 분산 실시에 따른 연계성 확보 문제

- 중장기 $\mathrm{ODA} / \mathrm{MDGs}$ 추진 전략

- $\mathrm{OECD}$ 개발원조위원회(DAC)의 회원자격

48. (1) 개발원조의 법적 기반을 마련하도록 가칭 〈국제개발협력법〉을 제안한다.

- 현재의 한국국제협력단법 및 대외경제협력기 금법의 이원적인 사업법 체계 하에서 유·무 상원조에 공히 적용할 수 있는 통합적이고 미 래지향적이며 일관성 있는 ODA 비전과 철학, 기본 목표 및 효율적 수행원칙 등을 명시적으 로 규정하지 못하고 있다.

- 한국의 경우 최근 수년간 우리나라의 ODA 규 모는 급증하고 있는데도 불구하고 개발원조 의 철학과 이념 및 기본원칙이 불분명하고 정 책일관성을 제고하는 것이 요청되고 있다.

- (가칭)국제개발협력법의 운용을 통하여 통합 적 원조정책을 구현하면서, 대외원조자금의 투명성과 효율성을 확보할 수 있을 것이다.

49. (2) 한국의 개발원조는 몇 갈래로 분산적으로 추진되고 있어서 그 효율성에 대한 검증이 필 요하다.

- 하나는 유 - 무상원조가 재정경제부의 감독을 받고 있는 수출입은행과 외교통상부의 감독 을 받고 있는 한국국제협력단으로 각각 나누 어져 있다는 점이고, 다른 하나는 무상원조사
업 자체에 있어서도 부처간에 산발적으로 추 진되고 있다는 점이다.

50. 먼저, 전자의 유·무상원조의 비연계성은 앞 으로 원조 규모의 증대와 국별 원조계획 하에 서의 개발원조로 전환된 경우 반드시 시정되 어야 할 과제이다.

- 한 국가가 단순한 지원자금의 금융조건의 차 이 때문에 개발협력 사업을 아무런 연계성 없 이 각각 추진할 경우 상당한 낭비와 비효율성 이 수반될 것이다.

- 이러한 문제점에 대응하여 최근 국무조정실 에 “국제개발협력위원회” 를 설치하였지만, 개 발원조가 유기적으로 체계적으로 수행될 수 있기 위해서는 기구 설치와 아울러서 그것을 가능하게 하는 여건의 조성이 필요하다.

- 기왕에 설치된 국제개발협력위원회의 기능을 활성화할 수 있도록 실무적인 협의 조정 및 다 양한 전문적 자문기능을 갖출 것이 요구된다.

- 이와 같은 시스템을 운영하면서 그 성과를 꾸 준히 평가하여 보다 효과적인 원조체제의 정 비 방안에 대하여 논의해 나가야 할 것이다.

51. 다음으로, 후자의 무상원조사업 각 정부기관 의 분산 추진 문제와 관련하여 두 가지 점에서 비효율성이 수반되고 있다.

- 2005년 현재, 외교부와 KOICA를 통하지 않 고 있는 무상 $\mathrm{ODA}$ 사업은 1,300 만 달러에 달 하고 있으며, 이는 10 개 부처와 8 개 청, 1 개 
위원회 등을 통하여 실시되고 있다.

- 원조 사업이 서로 연계성 없이 추진되어 중 복, 낭비의 우려가 있고 제한된 재원을 분산 적으로 활용하고 있어서 효과성도 낮다.

- 각 기관은 개발원조사업 추진의 전문성이 미 흡하기 때문에 전문적인 사업관리가 이루어 지지 못하고 있다.

52. 그런데 이러한 분산 추진의 경향이 확대되고 있는 요인은 다음과 같은 점에 기인한다.

- 무엇보다 외교통상부 감독 하의 $\mathrm{KOICA}$ 를 통 한 무상협력사업이 정부 각 기능별로 다양한 개발협력 수요를 충분히 수렴하지 못하고 있 다. 특히 한국의 개발원조는 기관이기주의에 의하여 일본에서 볼 수 있는 각 부처의 공동참 여가 이루어지지 못하고 있다.

- 개발도상국가에서의 한국의 개발협력 수요가 아주 다양하게 전개되고 있다.

- 각 부처 및 기관으로서도 개발도상국과의 협 력관계를 가질 필요성이 있으며, 스스로 기능 을 확대하려는 속성을 가지고 있다.

53. 이상과 같은 분산적 무상원조사업 운영에서 오 는 비효율성을 극복하기 위하여 다음과 같은 무상원조사업 운영체계의 조정이 필요하다.

- 당장 무상원조사업을 무상원조사업 전담실시 기관인 $\mathrm{KOICA}$ 로 통합하는 것은, 현재의 $\mathrm{KOICA}$ 운영조직이 정부 각 기능의 개발협력 수요를 효과적으로 수렴하기에는 미흡함으
로, 무리라고 판단된다.

- 우선적으로 $\mathrm{KOICA}$ 는 각 부처가 가진 전문적 지식을 보완하여 개발도상국 및 각 부처로부 터 제기되는 해당 분야의 전문적 개발협력 사 업을 효과적으로 수용하여 추진할 수 있는 체 제를 갖추어야 한다.

- 그러나 각 부처의 사업 중에서 전체적인 무상 원조사업의 틀 안에서 추진되는 것이 바람직 한 사업은 추려서 무상원조 전담실시 기관인 $\mathrm{KOICA}$ 로 통합하는 것이 바람직하다.

- 부처별 무상원조 사업은 전체적인 원조계획 의 틀 안에서 조정될 수 있도록 하는 것이 필 요하다.

- 부처별 전문성을 살려야 할 협력사업은 자율 적으로 수행할 수 있도록 하되 관련 예산은 $\mathrm{KOICA}$ 의 무상원조 예산에 편성하거나 통합 적인 국제협력 관련 예산제도를 운영하는 방 안의 검토가 필요하다.

54. (3) ODA/MDGs 추진전략계획을 수립 운영하 여야 한다.

- 빈곤 극복에 독자적인 경험과 노하우를 보유 하고 있는 한국으로서는 MDGs 실천계획에 어느 나라보다도 앞장서야 하는 책무를 가지 고 있으며, 그것이 한국의 국가적 이익에 부 합하는 것이다.

- 한국도 선진국의 사례를 참고하여(가칭) 『중 기(2006-2015) ODA 및 MDGs 추진전략계 획』을 마련하여 대내외에 공표할 필요가 있 
다. 이 작업은 관계부처 및 민간 전문가의 참 여하에 MDGs 실천 기본방향과 전략, 단계별, 분야별, 지역과 국별 주요 추진계획을 포함하 는 것이 되어야 한다.

55. (4) 한국으로서 개발원조가 핵심적인 국가전 략이라면, $\mathrm{OECD} / \mathrm{DAC}$ 가입은 빠르면 빠를수 록 국가적 이익이 되는 것이다.

- $\mathrm{OECD} / \mathrm{DAC}$ 에 가입 시기는, 우선 그 가입 조 건의 충족과 회원국 가입 후, 개발원조 수행 시스템 하에서 우리의 이익을 지킬 수 있는 준 비에 소요되는 기간을 감안하되, 가능한한 빠 른 것이 바람직하다.

- 전자의 경우, 개발원조의 규모에 있어서는 최 소한의 기준을 충족하고 있으나, 개발원조의 GNI 비중에 있어서는 국제적인 관행에서 크 게 뒤떨어져 있다. 그리고 원조의 질적 기준 에도 크게 미흡하다. 무상원조의 비중, 증여 율을 국제적인 기준에 근접시켜야 하고, 원조 의 언타이드화도 국제적 수준으로 실현하여 야 할 것이다. 그리고 개발원조의 수행방식이 국제적 관행에 적합하도록 이루어져야 한다. 이들을 실현함에 있어서는 지금부터 서두르 더라도 상당한 시기가 걸릴 것이다.

- 후자의 경우 국내 원조시장의 개방 하에서 우리가 충분한 수주 경쟁력을 갖출 수 있어야 한다. 그렇지 못하면, 그 가입이 경제적 부담 만 초래하고 이득은 선진국 기업들의 몫이 되 고 만다. 이 역시 우리가 과감하게 추진하더
라도 상당한 기간을 요한다.

- 이 두 가지 조건을 더 이상 늦기 전에 충족할 수 있도록 하여 가능한 한 조기에 $\mathrm{OECD} / \mathrm{DAC}$ 회원국으로 가입할 수 있어야 한다.

56. 둘째, 개발원조의 재원의 동원과 배분의 방안 과 관련하여 다음과 같은 체제가 마련되어야 한다.

(1) 개발원조 재원의 확대와 유 · 무상원조에 의 배분

(2) 재원활용의 선택과 집중

(3) 재원기반 확충 및 원조사업의 중기성을 뒷받침할 수 있는 예산 관리제도

57. (1) 개발원조 재원의 확대와 유 - 무상원조에의 배분의 문제에 있어서, 우선 개발원조 재원의 지속적인 확대가 이루어져야 한다.

- 정부는 중기재정운영계획으로 2009년까지 $\mathrm{ODA}$ 규모를 GNI 대비 0.1\%까지 확대하여, 총 ODA 규모를 9.1억 달러로 잡고 있으며, 특 히 양자 원조 중에서 유상원조가 $54.6 \%$, 무상 원조가 $45.4 \%$ 를 차지하는 것으로 계획되어 있다.

- 먼저, $\mathrm{ODA}$ 규모의 적정성과 관련하여, 2009 년 GNI 대비 $0.1 \%$ 는 한국으로서는 쉽지 않은 목표이지만, MDGs 달성을 위한 원조공여국 들의 $\mathrm{ODA}$ 재원 확대 계획에 비추어서는 상당 히 미흡한 수준이다. 따라서 중장기적으로 국 제사회의 기준에 접근할 수 있도록 재정기반 
을 지속적으로 확대함과 아울러, 그 배분에 있어서 $\mathrm{ODA}$ 에 우선순위를 둘 수 있는 여건을 조성하는 것이 긴요한 과제이다.

- 국제적 기준에 비추어서는 아주 보수적으로 잡아서 2015년까지 우리나라의 ODA를 현 $\mathrm{DAC}$ 평균 수준인 0.26\%(2004년도 추정치) 로 확대할 경우 2010 년까지는 최소 $0.16 \%$ 수 준까지 증대시켜야 할 것으로 판단된다.

- 이렇게 볼 때, 우리의 개발원조는 아주 보수 적으로 보더라도 현재와 비교해서는 그 규모 가 크게 늘 수 밖에 없는데, 사실은 원조의 규 모의 증대와 아울러 이를 효과적으로 관리하 고 쓸수 있는 체제를 마련하는 것이 더욱 긴요 해 지고 있다.

58. 다음으로, 개발원조의 규모 안에서 양자간 원 조의 유·무상 재원의 배분이 합리적으로 이루어져야 한다.

- 중기재정계획상 양자간 원조의 유 · 무상구조 를 보면 유상원조 비중이 무상원조의 그것보 다 높은 것으로 책정되어 있다.

a 유상원조를 옹호하는 입장에서는 무상원조가 수원국의 도덕적 해이와 자립의지에 부정적 인 효과를 줄 수 있으며, 한국은 선진국과는 달리 개발도상국가에 대한 역사적 부채가 없 다는 점을 내세운다.

- 반면, 무상원조를 옹호하는 입장에서는 국제 적 기준이 무상원조를 중심으로 공여하고 있 으며, 증여율과 증여비율을 지속적으로 낮추
어가는 것이 국제적 관행이기 때문에 우리도 이에서 벗어나는 것은 바람직하지 않다는 입 장이다.

- 이 문제는 어느 원조가 반드시 옳고 다른 방식 은 그르다는 판단은 할 수 없는 것으로 판단된 다. 유상원조의 논리도 무상원조를 부정하는 것이 아니라 유상원조도 나름대로 타당성을 가지고 있다는 논리이다.

59. 아래와 같은 관점에서 한국의 현재와 같은 높은 유상비율은 바람직하지 않은 것으로 보 인다.

- 개발원조의 국제적인 경향에서 볼 때 현재 한국의 높은 유상원조 비중과 낮은 증여율은 아주 예외적인 것이며, 유상원조를 하고 있는 국가들, 예를 들어 일본, 호주 등도 최근 유상 원조의 비중을 더욱 줄이고 있다.

- 우리나라의 ODA 질을 향상시켜서 우량의 공 여국으로 평가 받는 것이 국익에도 도움이 되 는바, 중장기 $\mathrm{ODA}$ 확대전략에서 유·무상원 조의 구성 비율을 단계적으로 무상 중심으로 전환하는 것이 바람직하다.

- 그러나 유-무상원조 사이의 재원배분 보다 더 중요한 문제는 원조재원의 효과성을 살리 는 노력이다. 개발원조의 재원을 늘리고 금융 조건을 유리하게 만드는 것만이 능사가 아니 라, 한정된 재원을 효과적으로 쓸 수 있도록 개발협력의 개혁을 실현하는 것이 더욱 긴요 하다. 
60. (2) 제한된 $\mathrm{ODA}$ 재원으로 최대의 효과를 거양 하기 위해서는 $\mathrm{ODA}$ 사업을 선택과 집중의 원 리에 의하여 개발협력 대상국을 대폭 줄이고, 소수 프로그램에 집중적으로 지원하여야 한다.

- 개발원조사업이 효과적일 수 있기 위하여서 는 먼저, 그 사업이 정책 프로그램과 연결되 어야 하고, 소기의 성과를 거둘 수 있도록 일 정 규모 이상으로 다년간 지속되어야 할 것이 요구된다.

- 선진국 원조의 경우 최소한 우리보다 10-20 배 이상의 원조 규모를 가지고 30 개 수준의 국가를 대상으로 2-3개 소수 프로그램을 가 지고 집중적으로 지원하고 있음은 오랜 원조 의 역사를 통하여 얻어진 원조의 성과를 거두 기 위한 노하우이다.

61. 이러한 선택과 집중의 원칙에 비추어 한국의 무상원조사업은 다음과 같은 방향으로 조정 될 것이 요구된다.

- 중장기 국별 원조 프로그램(CP)을 가지고 집 중적으로 지원함으로써 개발협력의 빈곤 극 복의 가시적인 성과가 거양될 수 있도록 하여 야 한다.

- 대상국의 선정에는 “선택과 집중” 전략이 요구 된다. 국별 원조계획에 의한 협력대상국은 최 대한 15 개국 이내로 하는 것이 바람직하다.

62. (3) 한국의 재정상 제약성과 개발원조사업을 국별 원조계획에 의하여 수행할 수 있도록 하
기 위하여서는 개발원조 재원기반의 확충 방 안을 검토하며, 예산관리제도의 개선이 필요 하다.

- ODA 재원의 효율적 운용을 위해서는 3-5년 간의 집중적이고 예측 가능한 국별 프로그램 방식으로 지원이 가능하도록 예산제도 운영 의 다년도화와 신축성 확대가 필요하다.

- 전략적인 다년간 예산지원 제도 운영을 통해 $\mathrm{ODA}$ 재원의 낭비요인을 사전에 방지할 수 있 을 뿐 아니라, 중장기적 관점에서 $\mathrm{ODA}$ 재원 에 대한 성과 측정과 성과 관리 및 평가가 가 능하고, 원조효과도 배가되어 원조 자금의 투 명성과 효율성, 신뢰성이 증대되는 효과를 거 양할 수 있다.

- 아울러, 소액 다국 분산방식의 개발원조를 지 양할 수 있기 위하여서는 (가칭) 신속개발협력 기금(Rapid Development Assistance Scheme ; $\mathrm{RaDAS})$ 의 설치 운영이 필요하다.

63. 셋째, 사업관리 시스템을 단계별로 합리적으 로 관리할 수 있도록 하는 관리 방안을 제시 한다.

(1) 프로그램의 기획, (2) 사업의 시행, (3) 사 업에 대한 평가와 환류(feed back)의 관리체 계의 기본적 사업관리 절차와 아울러 (4) 정 보관리와 (5) $\mathrm{KOICA}$ 의 조직체계를 검토한다.

64. (1) 프로그램의 기획은 사업의 성과를 결정하 는 첫 걸음이다. 그 기획이 제대로 되지 아니 
한 경우, 그 다음 단계에서 아무리 재원을 많 이 투입하여 사업을 시행하였다고 하더라도 허사가 되고 만다.

- 프로그램의 기획은 연구조사 기능이다. 따라 서 원조기관은 연구조사를 통하여 국별 정책 프로그램을 설계할 수 있는 능력을 갖추어야 한다. 연구조사가 원조기관의 핵심적인 역량 이 되어야 한다.

- 특히 한국으로서는 다른 선진국과는 달리 빈 곤극복과 경제개발의 지식과 노하우를 개발 원조에 접목할 수 있도록 연구가 뒷받침되어 야 한다.

- 원조기관이 이러한 기획기능을 효과적으로 수행할 수 있기 위하여는, 기존의 사업시행, 평가 등 업무를 과감하게 시장에 위탁하고 원 조기관은 기획 능력의 배양에 주력하여야 할 것이다.

65. (2) 사업의 시행은 현재 KOICA, 정부 출연기 관, 시장에서의 선정 등 혼합적 방식으로부터 보다 전적으로 시장에 의존하는 방식으로 전 환하는 동시에 $\mathrm{NGO}, \mathrm{NPO}$ 등과의 파트너십 을 확립하는 것이 바람직하다.

66. (3) 대외원조 사업은 효과성(effectiveness)과 효율성(efficiency)을 평가받아야 하고, 그 결 과가 환류될 수 있도록 하여야 하는데, 이 점이 우리의 사업관리에서 특히 취약한 부분이다.

- 평가는 통합적인 원조계획의 일부이다. 이는
원조의 투명성과 효율성을 제고하기 위해서 뿐만 아니라, 형식적으로 $\mathrm{DAC}$ 가입을 위하여 서도 전문적이고 독립적인 $\mathrm{ODA}$ 평가 시스템 을 갖추는 것이 필요하다.

- 별도의 ODA 평가위원회 등을 구성하여 ODA 백서를 발간하도록 하고 이를 국회를 통해 보 고하며, 국민들에게 공개하도록 하여야 한다.

- 무엇보다 필요한 것이 외부 전문가들로 구성 되는 “원조평가위원회” 를 통해 평가를 수행하 고 모든 평가 보고서는 공개되고 인터넷을 공 개하도록 하는 것이다.

67. (4) $\mathrm{ODA}$ 과정에서 생산되는 정보를 효율적으 로 관리하여 국가적으로 또는 개발원조 사업 에서 유용하게 활용될 수 있도록 하여야 한다.

- 우리나라는 1990년대 이후 본격적으로 대외 원조를 시작한 이래 아직까지 개도국에 대한 종합적 지식-정보-인력네트워크를 마련하지 못하고 있다.

- 정보를 제대로 생산하고 이를 효과적으로 활 용될 수 있도록 하자면 정보의 생산과 그 수요 의 양면에 걸쳐서 대책이 필요하다.

- 먼저 정보의 생산 및 공급을 위하여, 현장의 정보를 데이터베이스화하여 체계적으로 관리 하는 시스템이 갖추어져야 할 것이다. 해외 파견인력이 현장정보를 온라인으로 입력할 수 있도록 하고, 그 입력 정보를 분야와 등급 을 부여하여 체계적으로 가공하는 것이 필요 하다. 
a 정보의 생산이 수요와 제대로 연결되지 못할 경우, 그 정보의 생산은 막대한 비용만 초래하 고 결국 사장되어 재생산이 되지 못한다. 개발 원조 사업의 추진 방식이 시장에서 용역을 조 달하는 방식으로 바뀔 경우 개발원조 전문 비 즈니스가 창출되고 그들에 의해서 정보가 값 지게 가공 활용되는 환경을 만들어야 한다.

- ODA 종합 네트워크(가칭 'KorAID Net')를 구축할 경우, 원조사업의 계획과 사업, 사업 시행 및 평가에 이르기까지 효율적인 정보와 인력 활용이 가능하며 경제적 협력관계의 심 화에도 크게 기여할 수 있을 것이다.

68. (5) $\mathrm{KOICA}$ 가 이상과 같이 무상원조사업 관리 의 전문화를 기할 수 있기 위하여서는 조직 운영에 있어서 혁신이 있어야 할 것이다.

- 한국국제협력단(KOICA)은 일본의 JICA를 벤 치마킹하여 1991년에 창립되었으며, 설립 당 시 2 천만 달러 정도의 소규모 예산을 120 여 국가에 나누어주는 방식으로 인력사업과 기술 협력, 소규모 개발사업을 주된 원조사업으로 하는 기능형 사업조직이었다. KOICA는 발족 부터 사업형태별 수행 조직 모델을 근간으로 하고 있었으며, 재원의 규모, 조직의 운영체계 와 기능이 매우 초보적인 단계의 사업별 개발 원조 편제를 지속하여 왔다고 할 수 있다.

- $\mathrm{KOICA}$ 는 무상원조 전문 책임기관으로서 전 문적인 지식경영을 실천하고 지역관리 능력을 극대화할 수 있는 조직으로의 획기적인 변모
가 필요하다. 그 형태는 선진국 원조기관의 일 반적 원칙인 혼합형 조직구조가 바람직하다.

a 원조기관의 일반적인 조직 형태는 정책과 기 획, 원조조정, 평가, 관리 등을 총괄하는 정책 관리국, 국별 프로그램을 집행하는 지역국 그 리고 주요 이슈와 분야별 프로그램을 수행하 는 기능국이 함께 공존하는 체계이다. 선진화 된 원조사업관리를 할 수 있기 위해서는 이러 한 혼합적 형태가 바람직하다.

69. 넷째, 무상원조사업을 다시 현행의 개별 사업 별로 고찰하여, 이상의 중장기 정책 프로그램 이 조기에 연착륙할 수 있도록 그 개선방안을 제시한다.

ם 현행의 연수, 개발조사 등의 사업별 예산배분 의 우선순위가 관심이 될 수 있으나, 재원배 분의 기준은 개발협력사업, 연수사업, 물자공 여 등의 사업단위별이 아니라 국가별 정책 프 로그램의 중요성과 그 재원소요에 따라 먼저 정책 프로그램별로 재원이 배분이 되고, 그 다음으로 정책 프로그램을 달성하기 위한 방 법으로 소요되는 개별 사업에 대한 재원배분 이 이루어지는 방식이 되어야 한다.

70. (1) 인력협력 사업과 관련하여, 연수사업은 개 발도상국가의 정책 담당자들로 하여금 그들 이 빈곤 극복과 경제개발을 촉진함에 있어서 필요한 지식과 노하우를 전수하는 유용한 사 업이다. 그런데 본 사업이 효과적으로 수행될 
수 있기 위하여서는 다음과 같은 점에서 개선 이 요망된다.

- 무엇보다 연수계획이 국별 정책 프로그램 체 계 하에서 수립되어야 한다.

- 연수의 내용이 단순히 한국의 발전경험을 소 개하는 수준에서 머물 것이 아니라, 그들이 당면하는 문제해결을 위한 지식과 노하우를 제공하는 것이어야 한다.

- 이러한 맞춤형 연수는 이를 본업으로 하지 않 는 출연기관에 부수적 사업으로 위탁하는 방식 으로는 실현되기 어렵다. 가능한 한 시장에서 연수 전문기관을 선정하는 것이 바람직하다.

71. 그런데 연수 프로그램이 단기 연수가 아니라 장기적인 대학에서의 정규 교육으로의 전환이 바람직하다는 주장이 제기되고 있지만, 다음 과 같은 점에서 반드시 타당한 견해라고 보기 어렵다.

- 선진국 원조에서 대학에의 정규 교육을 위주 로 하는 것은 그들이 한국이나 일본과 같이 개 발도상국이 필요로 하는 실용적인 연수 프로 그램을 별도로 제공할 수 있는 입장이 못 된다 는 사실과도 관계가 있다.

a 한국은 대학의 정규 교육으로서는 수행하기 어려운 실용적인 개발경험을 아주 다양하게 보유하고 있으며, 이러한 지식의 전달은 정규 교육기관의 학위 과정으로서는 다루기 어려 운 것이다.

72. 컨설팅을 위한 전문가 파견은 특히 위와 같은
이유로 다음과 같은 점을 감안하여 개선할 것 이 요구된다.

- 전문가 파견은 반드시 수원국에 대한 정책 프 로그램의 일환으로 운용되어야 한다. 그럴 경 우 특정 정책 프로그램을 실현하기 위하여 전 문가의 자문, 초청 연수 등의 여러 사업이 함 께 수행될 것이다.

- 전문가 파견의 목적이 특정의 정책 프로그램 의 달성에 있기 때문에, 개인에 의한 단기적 파견이 아니라 복수의 팀에 의하여 수행되는 것이 필수적이다.

- 의료진 파견도 단순한 질병 치료에 그칠 것이 아니라 수원국의 의료기술과 의료서비스 환 경을 개선하는 정책과 연계될 수 있도록 하는 것이 바람직하다.

73. (2) 개발협력 사업은 그 성격상 국별 원조계획 을 실현하는 직접적 사업수단이 되는 바. 새 로운 사업관리 체계 하에서 수행방식과 내용 이 크게 달라져야 한다.

- 앞의 인력협력 사업과 마찬가지로 국별 원조 정책을 기초로 이를 달성하기 위한 수단으로 수립되어야 한다.

- 개발협력 사업의 내용이, 한국의 발전경험을 개발도상국에 유용하게 활용한다는 의미에서 물자나 하드웨어 제공의 사업에서 탈피하여, 그들의 발전을 지원할 수 있는 소프트웨어 및 지식 위주의 개발협력으로 그 내용이 바뀌어 야 한다. 
- 국별 개발정책 프로그램은 선진국이 제공하 기 어려운 한국의 개발경험의 성과를 활용하 는 것이 절대적으로 중요하다.

- 이러한 개발협력 사업을 효과적으로 추진할 수 있기 위하여서는 개발원조를 전문으로 하 는 컨설팅 산업의 기반이 있어야 한다.

74. (3) 한국해외봉사단 $(\mathrm{KOV})$ 파견사업에 대해서 는 현재 추진되고 있는 파견인력의 대폭적 증 대 구상의 타당성과 파견인원의 증대에 따른 인력관리 시스템에 대하여 검토하였다.

75. 파견인력의 증대 자체가 개발원조의 이념과 직접적인 관계가 있다기 보다는 문제는 파견 인력의 증대로 개발원조의 이념이 퇴색될 정 도의 질적 수준 저하 및 관리상의 문제를 수 반하지 않도록 하는 것이 필요하다.

76. 파견인력을 국가적 수요에 따라 증대하는 동 시에 개발원조의 이념에 충실한 봉사가 될 수 있도록 봉사단 파견 사업의 운영방식 전환이 필요하다.

- 봉사단의 수요를 적극 개발하고 동시에 공급 면에서 철저히 대비하여 무작정 파견 인원수 의 증대에서 오는 봉사의 질적 저하와 개발협 력의 취지 훼손이 없도록 하는 것이 필요하다.

- 봉사단의 임무를 조정하여, 봉사단을 국별 원 조프로그램의 일환으로 활용하자는 것이다. 예를 들어 아프리카의 새마을 운동 프로그램
을 추진할 경우 막대한 청년인력 수요가 창출 될 수 있을 것이다.

- 봉사단의 신규 수요국가를 적극 개발하여야 한다. 개발도상국가로서 비 개발원조대상 국 가를 개척하는 것도 그 하나의 방법이다.

- 공급면에서 파견인력에 대하여 전문적 교육 훈련기관을 통하여 종합적이고 철저한 훈련 을 받도록 하는 것이 필요하다.

- 청소년위주의 봉사단이 가진 단점을 보완할 수 있도록 학습비용을 줄이고 경험과 노하우 를 가진 퇴직자의 파견을 확대하는 것도 필요 하다.

- 봉사단 관리 시스템은, 1 단계에서 $\mathrm{KOICA}$ 의 봉사단 파견의 기획 기능을 강화하여 중장기 파견 프로그램을 마련하는데 주력도록 하며, 파견인력 교육 훈련은 외주에 맡겨 철저한 봉 사 정신으로 무장할 수 있도록 하고, 2 단계로 그 실시 경험을 토대로 장기적으로 독립기구 를 설립하여 봉사단 파견을 전담하는 방안을 검토해 볼 수 있을 것이다.

77. (4) NGO 등 민간의 국제협력 활동 지원과 관 련하여, 이들에 대한 지원비중을 늘려나가되, 사업의 수탁뿐만 아니라 개발원조의 전 과정 에서 이들 민간기구와의 진정한 파트너십을 확립하는 것이 필요하다.

- 아직 역사가 일천한 개발 $\mathrm{NGO}$ 의 맹아적 수 준을 감안 할 때, $\mathrm{NGO}$ 활동을 활성화할 수 있 도록 무상원조 중에서 $\mathrm{NGO}$ 사업에 대한 지 
원 비중을 늘리는 동시에, 개발 $\mathrm{NGO}$ 의 특성 화 전략을 만들어 장기적인 관점에서 이를 유 도할 필요가 있다.

- NGO를 포괄하는 범국가적 가칭 「긴급구호위 원회(Humanitarian Relief and Assistance Committee)」를 운영하여 국제적 지역분쟁과 재난 발생에 효율적으로 대응할 수 있도록 하 는 것이 필요하다.

78. 본 연구의 넷째 과제는 이상과 같이 논의한 무상원조의 정책 틀 안에서 담아야 할 컨텐 츠, 즉 한국이 가진 빈곤극복 및 경제 개발의 노하우를 녹인 한국형 개발협력 모델을 제시 하는 것이다.

ם 한국형 개발협력모델이란 개발원조의 기본목 적인 국제사회의 빈곤완화를 한국의 독특한 발전경험을 바탕으로 한 한국의 비교우위를 활용하는 한국의 개발협력 방식이라고 할 수 있다.

- 본 연구에서는 그 동안 필요성만 주장되어오 던 한국형 개발협력모델을 구체적으로 설계 하고 있다.

79. 한국적 개발협력모델이 국제사회의 빈곤을 해 소하는데 효과적으로 기여할 수 있기 위하여 서는 무엇보다 개발도상국가의 여건에서 빈곤 의 환경적 및 대내적 요인분석을 토대로 이를 효과적으로 공략하는 것이어야 할 것이다.
80. 개발도상국의 빈곤은 여러 문제가 복합적으 로 얽혀 있지만, 이를 구별하면 크게 네 가지 로 나누어 볼 수 있을 것이다.

- (1) 국민 의식적 측면에서 빈곤 국가들의 국민 은 일반적으로 오늘날의 선진국의 그것과 는 다른 의식을 가지고 있다. 무엇보다 역 사적 과정에서 식민지 지배 또는 사회주의 경험에 그 의식에 영향을 받을 수 밖에 없 었다. 이러한 역사적 환경에서 자립의지의 결여, 열등의식, 의타성, 근로의욕의 미흡 등의 의식적 특성이 선진국 국민들에 비하 여 상대적으로 두드러진다.

- (2) 거버넌스(Governance)의 부재이다. 개발 도상국가에 있어서는 대개 법치가 제대로 이루어지지 못하고 있다. 그리고 공공서비 스에서 부패와 비효율성이 만연하고 있다. 대게 이는 지배권력의 부패와 연결되어 있 기도 하다.

- (3) 제도(Institution)와 현실의 괴리이다. 많 은 국가에서 선진 민주주의 및 시장제도가 이식되어 있으나, 이들 제도와 문화적 토 양의 불일치로 제도가 제대로 작동하지 않 고 역기능을 수반하는 경우가 많다. 그 한 가지 예가 부가가치세제이다. 산업이 아주 유치한 단계에서 고율의 부가가치세가 조 세징수 과정에서 부조리의 온상이 되고 있 으며 산업의 태생을 제약하는 구조적 토양 을 만들고 있다.

- (4) 글로벌 국제환경에서 기업 성장의 어려움 
이다. 무역 및 자본 자유화의 WTO체제 하 에서 세계적인 경쟁력의 기업에 시장이 개 방되어 있는 여건에서 걸음마도 하지 못하 는 신생 토종 기업들이 생겨나고 성장한다 는 것은 여간 어려운 일이 아니다. 기업이 탄생하지 못하는 여건에서 일자리를 마련 하고 소득을 증대시켜 빈곤을 벗어나게 할 수 없는 것이다. 더욱이 거대 중국이 세계 제조업의 기지로 부상하게 됨에 따라 개발 도상국가가 산업을 키워 일자리를 창조하 고 상품을 수출할 수 있는 여지가 더욱 협 소하게 되었다.

81. 특히 발전역량을 갖추기 위한 제도(Institution) 의 정비가 다음과 같은 이유로 거의 실패로 끝 나고 있다. 오히려 강제적으로 수용된 선진 제도가 오히려 부작용을 수반하여 사회적 발 전의 장애요소가 되기도 한다.

- 제도(Institution)의 공급 및 수요 측면을 수 용여건이 갖추어져 있지 못하다.

- 전자의 공급 측면에서 제도의 가능성이 상당 히 낮다(F. Fukuyama), 사회 전반적인 변화 에 필요한 시간은 길기 마련이고, 단기적 변화 는 단지 개별 조직이나 학교, 마을 등과 같은 매주 작은 수준에서 발생할 수 있을 뿐이다.

- 후자의 제도의 수요 측면에서 개발도상국가 에 있어서는 특히 수요가 미약하다. 어떠한 제도 개혁에도 이해가 상충되나 기득권층이 특권 상실을 감수하려 하지 않는다. 이러한
제도적 역량의 공급의 비 이전성과 그 수요의 불충분성의 여건에서 선진국은 자신의 제도 를 이전하고자 하였으나, 지금까지 그리 성공 하지 못했다.

82. 국제사회의 빈곤을 효과적으로 공략하기 위 한 한국형 개발협력모델은 다음과 같이 다섯 가지를 기본 골격으로 한다.

- 첫째, 빈곤을 효과적으로 극복할 수 있기 위 한 정책 프로그램의 개발

- 둘째, 선택과 집중의 원리에 따른 지원대상의 선정

- 셋째, 수원국의 여건에 부합하는 프로그램의 적용 방법

- 넷째, 정책 프로그램의 제작

- 다섯째, 산업적 인프라의 정비

83. 첫째, 한국형 개발협력모델로서 한국의 개발 경험을 바탕으로 개발도상국의 빈곤 극복 및 경제개발을 효과적으로 지원할 수 있는 정책 프로그램으로서 "Korea Initiative for International Development (KIID)"를 제안 한다.

84. KIID는 개발도상국가들이 빈곤을 극복하고 발전을 이루어나가는데 필요한 정책 프로그 램이다.

- 개발도상국가들이 발전의 과정에서 당면하는 중요한 경제적 및 사회적 제반 문제를 극복하 
기 위하여 필요한 전략을 제시하는 것이어야 한다.

- 신생국으로서 절대적 빈곤과 정치적 불안으 로부터 빈곤의 단계를 벗어나는 중진국 수준 으로 발전하기까지 극복하여야 할 핵심적 정 책과제이어야 한다.

- 그들이 그러한 과제를 실질적으로 해결할 수 있는 능력과 수단을 제시하는 것이어야 한다.

- 이를 위하여 빈곤 극복의 핵심적 요소인 기업 의 육성, 발전역량의 정비 및 국민의식을 효 과적으로 발전지향적인 것이 되도록 유도하 는 것이다.

85. 이 기준에 의하여 다음의 12 개의 정책 프로그 램을 선정하였다.

a P1. 국가건설(State Building) 및 경제개발을 위한 국가경영/전략(총론)

- P2. 개발정책 능력 배양(Capacity Building for Development Initiative)

- P3. 식량자급과 농촌 개발(Food Subsistence and Rural Development)

- P4. 새마을 운동 및 국민정신 함양

- P5. 가족계획, 국민보건 및 의료

- P6. 기술 기능 인력의 양성과 인적자원 개발

- P7. 공기업의 관리(Management of Public Corporation)

a P8. 국가 기간산업의 건설(Development of Key Industrial Plants)

- P9. 수출 진흥과 중소기업의 육성(Export
Promotion and SMEs)

- P10. ICT 산업의 육성

- P11. 거버넌스(Governance)와 공공 서비스

- P12. 글로벌화와 대외적 경제안정

(Globalization and Economic Security)

86. 이들 개별 프로그램에 대하여 다음과 같은 4 개의 기준 별로 검토하고 구체적인 내용을 제 시하였다.

- 본 정책 프로그램과 관련한 개발도상국가의 현상

- 그에 따라 개발도상국가들이 당면하는 발전 제약 요소

- 이러한 과제에 있어서 한국의 정책과 그 성과

- 한국적 경험의 개발도상국가에의 적용성 및 실현 방안

87. 둘째, 이러한 정책 프로그램을 적용할 대상을 선택과 집중의 원리에 의하여 선별하는 것이다.

- 개발협력의 대상을 지금과 같은 다수 국가에 대한 지원방식을 탈피하여 협력의 성격에 따 라 분류하는 것이다. 실질적 성과 거양을 위 하여 국가를 국별원조계획(CP:Country Programming)을 적용할 대상 국가를 선별 하여 이들은 우리의 원조규모에 비추어 1015 개 국가로 한다.

88. 이를 위하여 모든 개발원조 대상 국가들은 다 음과 같이 3 가지로 분류한다. 그 중에 앞의 
둘은 국별 원조계획이 적용되는 대상이다.

- 핵심협력국(Core Cooperation Country, $\mathrm{CCC}) ; 3-4$ 개 국가.

- 전략적협력국(Strategic Cooperation Country, SCC): 7- 12 개 국가.

- 일반협력국(General Cooperation Country, $\mathrm{GCC})$ : 그 이외 현재 협력대상으로서 $\mathrm{CP}$ 를 적 용하지 않는 국가.

89. 핵심협력국 (CCC)은 실패국가(Failing states), 절대빈곤 국가, 체제전환국가 중에 서 대륙별로 아래와 같이 선정하는 것이 바람 직하다. 그러나 중남미 국가는 지리적 여건을 고려하여 다음 단계에 포함하는 것도 검토해 볼 수 있다.

a 중앙아시아 또는 동남아시아 1 개국

- 아프리카 대륙 1 개국

- 중남미 대륙 1 개국

90. 이들 국가를 선정하는 기준은 다음과 같은 요 소를 포함하여야 한다. 이 중 가장 중요한 것이 첫째의 요소이다. 개발도상국가에 있어서 지도 자의 중요성은 거의 절대적이기 때문이다.

a 국가 지도자의 발전 의지와 도덕성

a 국민의 다수가 절대적인 빈곤 상태

a 체제 전환 또는 독립에 따른 정치 사회적 불안

- 한국적 개발정책에 대한 관심과 적극적 태도
91. 전략적협력국(SCC)은 인도적 및 외교적 차원 에서 협력이 긴요한 선별된 국가로서 그 범위 가 핵심협력국 보다 다소 넓은 것이다. 이들 국가들은 발전 단계와 수원국의 정책 수요에 맞추어 KIID Program 중에서 국별로 2-3개 를 선별 지원될 것이다.

92. 일반협력국 $(\mathrm{GCC})$ 은 통상의 외교적 차원에서 연수 물자공여 등의 일반적 지원대상 국가들 이다. 이들 국가들은 당장 원조를 줄이는 것 은 어려우므로 당분간 이를 유지하는 것이다.

93. 셋째, 정책 프로그램의 적용 요령으로서 내부 적으로 발전역량 및 제도에 대한 수요가 형성 되도록 여건을 조성하면서 소수의 정책 프로 그램을 집중적으로 적용하여 정책 프로그램 의 수용성을 확보하고 빈곤 극복의 가시적 성 과가 거양될 수 있도록 하는 것이다.

- 우선, 위와 같이 선정된 소수의 중점 목표국 가들에게 소수의 해당 정책 프로그램을 지속 성을 가지고 집중적으로 지원하고, 그 성과를 주기적으로 평가 환류토록 하여 기간에 뚜렷 한 변화가 있도록 하는 것이다.

- 다음으로, 위의 12 개 정책 프로그램의 적용 요령에 있어서 수원국의 발전 단계와 정책 프 로그램에 대한 수요창출을 바탕으로 이에 적 합한 프로그램을 적용하도록 하는 것이다.

94. KIID 12 개 정책 프로그램은 다음과 같이 발 
전 단계에 따라 연결고리로서 얽혀 있다. 이 러한 단계에 맞추어 해당 정책 프로그램을 적 용해 나가도록 하는 것이다.

\section{- 1단계:}

개발초기에 사회적 불안정과 절대적 빈곤의 여건 하에서 첫 단계로 요구되는 것이 국가적 질서유지와 국가 공권력의 확립(P1)과 개발정 책 능력형성/Capacity building(P2)이다. 그 러나 이 프로그램을 적용하더라도 두 가지의 근본적인 문제가 남는다. 하나는 국민의 기본 적 수요가 충족되지 못하고 있다는 점이요, 다
른 하나는 농촌을 중심으로 한 전근대성이다.

\section{- 2단계:}

국민의 식생활과 기본적인 보건을 어느 정도 해결하기 위한 식량자급과 농촌개발(P3), 가 족계획과 국민보건(P5)의 프로그램을 적용하 면서, 그 수단을 창출하는 수출 증대와 기업 탄생에 주력(P9)하는 프로그램을 강력히 추진 하는 것이다. 수출과 기업의 탄생이 이루어지 면서 두 가지의 과제가 생긴다. 하나는 기능 및 기술 인력 수요이요, 다른 하나는 도 - 농간 격차와 농민의 불만 또는 자각이 생기기 시작

〈해외재난 긴급구호종합관리 체계 〉

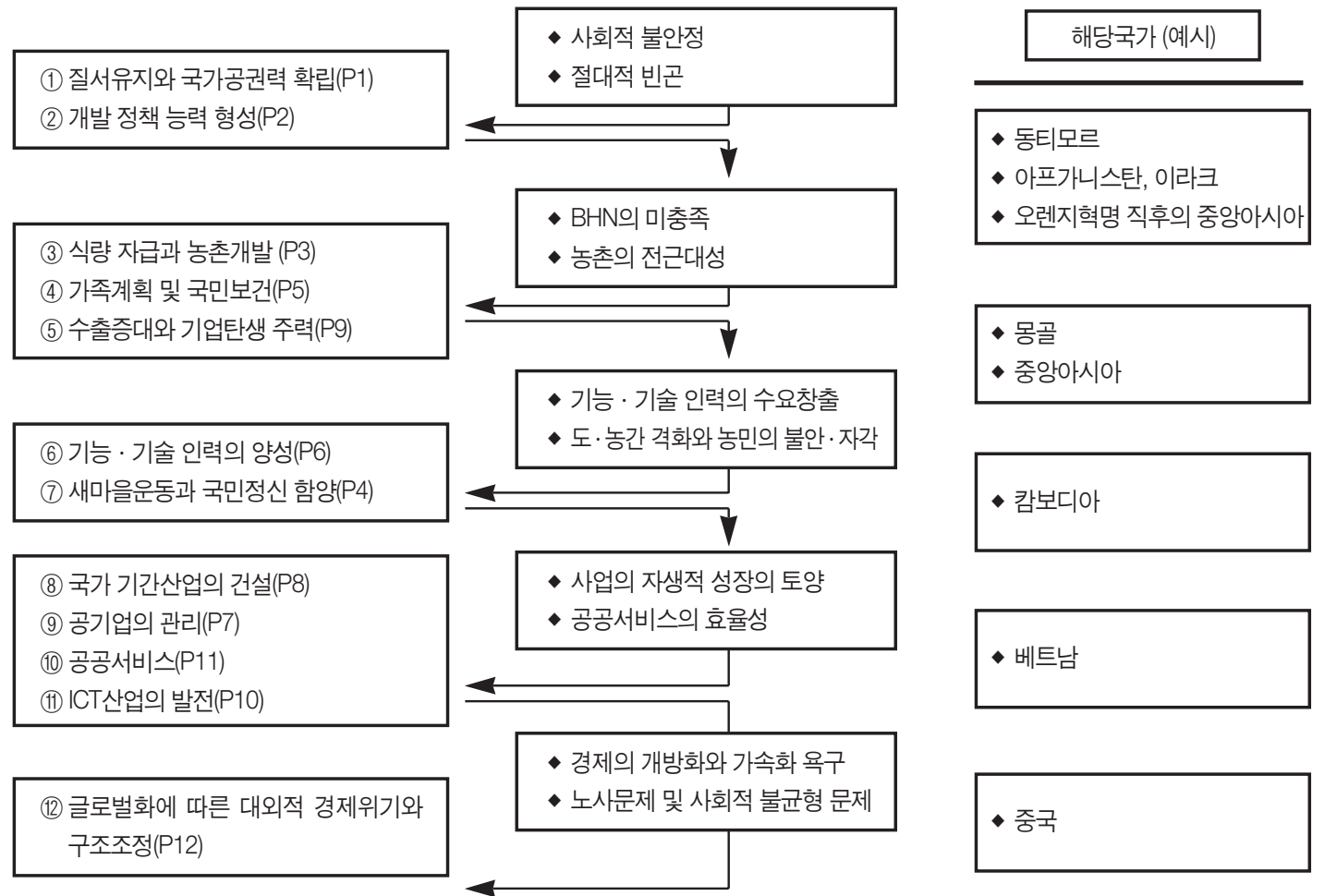


한다는 점이다.

\section{- 3단계:}

기능 · 기술인력 수요와 도 · 농간격차 및 농민 의 자각 기운에 대응하여 기능 - 기술인력 양 성(P6) 프로그램과 아울러 새마을운동과 국민 정신함양 $(\mathrm{P} 4)$ 프로그램이 필요해진다. 이러한 프로그램의 적용에 따라 산업의 자생적 성장 기반이 마련되기 시작하고, 산업 및 민간부문 의 성장에 따라 정부부문의 비효율성이 제기 된다.

\section{- 4단계:}

산업발전의 기반이 마련되면서 국가기간산 업의 건설(P8) 프로그램이 요구되고, 공공부 문의 효율성 제고를 위하여 공기업 관리 (P7), 거버넌스 및 공공서비스(P11) 프로그램 의 적용이 필요해지고, 산업 발전의 진전이 $\mathrm{ICT}$ 산업 발전(P10)으로 이어지게 된다. 이 러한 프로그램에 의해서 산업발전이 지속되 면서 경제의 개방화가 가속화되고, 노사문제 등이 불거진다.

\section{- 5단계:}

산업 발전의 지속에 따라 경제의 안정화 및 글 로벌화에 따른 경제위기의 가능성과 그에 따 른 구조조정(P12)의 필요성이 제기된다.

95. 특히, 핵심협력국(CCC)에 대해서는 먼저 국 가 지도자의 국가경영에 대한 비전과 전략적 우선순위에 대한 확신을 심는 것이 중요하다.

- 이를 위하여 특별히 설계되어야 할 것이 KIID
$\mathrm{P} 1$ 이다. 동 자료에 의하여 개발도상국가의 지 도자가 확신과 자신감을 가질 수 있기에 충분 하여야 할 것이다.

- 이를 바탕으로 해당 국가에 대한 진단과 국별 원조계획(CP)을 작성하여야 하는데, 이는 12 개 $\mathrm{KIID}$ 중에서 해당 프로그램을 중점적으로 적용하는 것이 될 것이다.

96. 이상과 같은 요령에 의하여 개발도상국가에 고질적 문제인 발전역량의 불비 및 제도의 비 수용성의 문제를 효과적으로 극복하면서 그 과정에서 국민의식이 발전 지향적으로 유도될 수 있도록 함으로써 고질적인 국제사회의 빈 곤극복의 효과성을 거양하고자 하는 것이다.

97. 넷째, 이러한 정책 프로그램을 효과적으로 전 수할 수 있기 위한 유형의 지적상품을 제작 활용하는 것이 필요하다. 그 방법으로 성격이 다른 두 가지 방법을 생각해 볼 수 있다.

- 하나는 동영상 $\mathrm{DVD}$ 를 만드는 것이다. 이것은 한국의 경제발전의 노하우를 녹인 생생한 시 청각 자료로서, 빈곤국가 및 그 국민들에게 자신감을 일깨우고 스스로 비전을 가질 수 있 도록 하기 위한 것이 그 취지이다.

- 다른 하나의 방법은 연구책자의 형태로 제작 하는 것이다. 이는 이론적 바탕을 가진 분석 보고서로서 정책담당자들의 정책 지침서로서 활용 가능토록 하는 것이 목적이다. 
98. 한국 개발협력 정책 프로그램 동영상 자료는 다음과 같은 목적을 가진 것으로 제작하는 것 이 바람직하다.

- 해당 정책 분야에 대하여 한국적 경험을 통하 여 개발도상국가가 문제를 해결해 나가는데 교훈이 될 수 있도록 한다.

a 발전의 핵심을 시각적으로 전달한다.

- 당시의 빈곤 및 경제개발에 대한 주역들의 생생 한 증언을 통하여 생동감을 줄 수 있도록 한다.

- 빈곤국가의 지도자와 국민에게 자신감을 고 취할 수 있도록 한다.

99. 동 DVD에 담을 내용은 다음과 같은 4 가지 사 항을 포함하면서, 당시 한국의 경험을 생생하 게 전달할 수 있는 개발정책의 주역, 근로자, 새마을 지도자, 농민, 기능공 등의 증언을 포 함하도록 한다.

- 본 정책 과제의 측면에서 본 개발도상국의 여건

- 그에 따른 개발도상국의 문제점

a 한국의 초기 여건과 발전 전략

a 한국의 전략 및 경험의 개발도상국에의 적용 성과 개발도상국이 취할 수 있는 바람직한 정책 방향

100. 이 같은 내용을 담은 DVD는 각 프로그램 별 로 각각 1 시간짜리로 제작하여 개발협력 사 업에 중요한 자료로서 그리고 국별 원조계획 의 수립, 프로젝트 개발, 연수 프로그램 등에
사용될 수 있을 것이다.

101. 다섯째, 이상과 같이 $\mathrm{KIID}$ 를 효과적으로 전 파하여 개도국의 빈곤을 완화하는 성과를 거 둘 수 있기 위하여서는 한국의 발전경험에 대한 전문적인 지식과 노하우를 축적한 개발 협력 컨설팅 기업들의 산업기반이 형성되어 있어야 가능하다.

- 이러한 정책 프로그램의 적용을 위하여서는 전문적 컨설팅 팀이 구성하여 구체적인 정책 방안이 마련되고, 이를 3-5년의 시계를 가지 고 집중적으로 지속하는 과정에서 매년 성과 의 평가와 그에 따른 프로그램의 조정이 이루어져야 할 것이다.

102. 개발협력 컨설팅 산업이 발전되어야 하는 추 가적인 근거는 개발협력 컨설팅 산업 자체가 세계 개발원조의 엄청난 규모의 시장으로서 한국이 가장 경쟁력있는 상품을 보유하고 있 는 잠재적 블루오션이기 때문이다.

- 세계 개발원조 시장의 규모는 현재로서도 선 진국 국민소득의 $0.26 \%$ 이나 앞으로 지속적 으로 확대될 것이며, 그 시장이 더욱 언타이 드화 될 것이고, 한국은 그 시장에서 가장 경 쟁력 높은 상품을 보유하고 있는 셈이다.

a 그런데 한국에서는 아직도 이러한 개발원조 산업기반이 형성되어 있지 못하다. 그러니 국제 시장에서의 그 엄청난 기회를 한국인은 인식하지도 못한 채 외면하고 있는 것이다. 
103. 이들 산업을 육성하여 그 과실을 거둘 수 있 기 위하여서는 지식 컨설팅 산업에 대한 지 원도 필요하겠지만, 그 보다도 중요한 것이 국내 개발원조 시장에서 실적을 쌓도록 하는 것이다.

104. 이를 위한 개발원조 사업의 운영은 두 가지 로 볼 수 있다.

a 하나는 앞 절에서 서술한 사업추진 체제를 정상화하는 것이다. 개발원조 사업이 개별 소규모 사업 공여 위주에서 정책 프로그램 위주로 바뀌고, 사업의 시행, 평가 등의 용역 을 시장에서 조달하게 되면 자연적으로 이 비즈니스를 하는 원조사업 전문 컨설팅 기업 들이 생성되게 될 것이다.

a 다른 하나는 사업 예산 단가 및 회계 관리제 도의 전반적 개편하는 것이다. 위와 같이 용 역을 시장에서 조달함에 있어서 그 사업 자 체만으로 충분히 비즈니스를 영위할 수 있을 정도의 인건비와 이윤을 보장하여야 한다는 것이다. 이를 위하여서는 원조사업의 예산 단가 및 회계 관리제도의 개편이 필요하다. 개발원조 컨설팅은 지식상품을 파는 것이므 로 지적 자산에 대한 가치를 제대로 평가하 여 보상될 수 있도록 하여야 함은 당연하다. 국제적 기준의 용역예산 단가를 적용하지 않 고서는 국제적 경쟁력의 컨설팅 산업이 발전
할 수 없을 것이다.

- 향후 5 년 동안 개발원조 산업기반을 조성하 여 가까운 시기에 선진국의 컨설팅 기업들과 같은 많은 기업들이 등장할 수 있도록 하여 야 할 것이다.

105. 이상과 같은 한국형 개발협력모델은 지금까 지의 선진국의 원조 프로그램과는 다른 독특 한 접근방법을 취함으로써 고질적인 국제사 회의 빈곤에 대하여 직접적인 성과를 거둘 수 있도록 하고자 하는 것이다.

- 독특한 한국의 발전 경험을 살려 개발도상국 가에 맞는 정책 프로그램을 개발한다.

- 이를 소수의 선택된 국가들을 대상으로 집중 적으로 지원함으로써 단기간에 가시적 성과 를 거둘 수 있도록 한다.

- 그 성과가 여타 빈곤 국가에 파급되어 다른 나라들도 빈곤극복과 경제발전의 의지가 점 화되도록 하고, 그에 맞추어 한국형 개발협 력모델의 보급을 확산해 나간다.

- 그 과정에서 한국은 국제사회에의 기여에 따 라 국제사회의 보다 신뢰받는 동반자로서 자 신의 브랜드 가치를 제고하는 동시에, 글로 벌 체제에서 지속적인 국가발전 기회를 창출 해 나갈 수 있게 될 것이다. 